\title{
Promoting ourselves on the web
}

\section{Brian Flaherty}

Scribbling this in front of a crackling fire in a hut at Arthur's Pass, a crisp night sky outside and a possum skating across the tin roof. We've spent the day walking in the hills above the village - up to the Devil's Punchbowl with Patrick on my shoulders, Annie and the other children up in front. Ten days away from computers, email and the Internet - a great relief?

It is easy to become isolated. I don't mean up here in the mountains, but in Auckland at a large University Library. You forget that many libraries don't have the same resources, the same budget, nor the same demand (yet) for the "e"s - e-journals, e-books, e-resources in general. (l've enjoyed wandering into small libraries while on holiday, feeling that sense of community and intimacy lost in larger organisations). But in another sense we are all facing the same challenges as librarians - how to retain our traditional skills and strengths while learning to harness the new technology.

There is no doubt that traditional circulation of books and serials will decline as we move through the various stages of hybrid libraries. The University of Auckland Library web gateway LEARN (the Library Electronic Academic Resources Network) for instance provides access to over 200 databases, 8,000 e-journals, hundreds of selected Internet resources and we are now starting down the road of acquiring e-books with a subscription to NetLibrary. The technology has not yet reached the stage where large chunks of text and even whole books can be read on screen - I think all of us when faced with more than two screens of de

nse text hit the print button - but this will happen. And in five to ten years time when reading devices are cheap, flexible and waterproof the old argument about reading in the bath will disappear. What student would not like to be able to fit all their text books, reference books and recreational reading into a portable, and easily readable device? There will certainly be a role for printed books
in libraries but it may not be our primary focus.

And it is not just content that is being delivered via the web. The University Library provides a number of electronic services - from e-reserves to "Ask a Librarian, an electronic reference desk. Many of our clients don't set foot in the physical Library. The Library web site received over 13 million hits in 2000 (an increase of $430 \%$ over three years) and the majority of these were from outside the Library, in computer labs, offices and from home. You'd be surprised how many people are
logged searching ABI-Inform at 4.00am!

All of this relies on increasingly sophisticated technology to authorise and authenticate clients and to deliver tailored information services to their desktop. What is becoming obvious is our reliance on technology. What do you do when your OPAC crashes? How many Dewey numbers can you pluck from memory to help clients browsing the shelves blindly? As we move more and more towards "virtual" libraries the stability of our computers, servers and networks becomes mission critical. My concern is that IT is often not seen as a shared responsibility but an annoyance or mystery that is pushed at the Systems Librarian or farmed out to commercial support services. IT staff are increasingly expected to bridge the gap between what their colleagues ought to know and what is
necessary to deliver library services.

This is not to say that many librarians are not rapidly learning new skills and some libraries provide excellent training for staff. And yes, we have learnt how to search the Internet efficiently and are reasonably comfortable with email. But as a group we like to portray ourselves as IT-savy professionals without really questioning our individual levels of knowledge. For instance, how many of us
can: 
unzip a compressed file?

upgrade a browser plug-in?

install a printer driver?

change our proxy settings?

defrag a hard drive?

These are basic skills that should be part of a computer drivers license for all librarians. How can we grapple with the large-scale "hybridisation" of our libraries and the related issues of maintaining and improving services to our clients if we can't explain to someone over the phone how to troubleshoot a simple problem with their computer. To quote Eric Lease Morgan "Why would anyone trust a librarian, whose profession is about information and knowledge, who hasn't mastered a computer?"

At the Online Conference (the biannual showcase for new library technology and innovation) in Sydney last January one librarian stood up and complained that IT people just don't understand us and our issues. She was greeted with empathetic murmurs. This had me squirming in my seat. Surely we should be the ones bending over backwards to understand IT professionals. We are asking them to lead the charge for us in current library "techno-wars" - the daily battles with technology. This is our information revolution but instead of driving the bus down the information highway, too often we are to be found in the back seat wishing it would just slow down.

How can we teach information literacy effectively when we are still struggling to become computer literate?

Where are the NZ librarians working on the Standards committees, pushing forward the important work on X500 directory services, Z39.50, XML protocols, EAD / RDF / Dublin Core and other metadata standards?

Why are most IT Librarians male? Does it reflect the general "boys with toys" explanation of the IT industry gender imbalance? Or is it also to do with the stereotypical image of our own profession - an aging, mostly female workforce, hesitant perhaps to get "down and dirty" with computers. My intention in pointing this out is not to offend anyone but to question some of our responsibilities as librarians. At a recent AGM of the LIANZA IT-SIG five people turned up, all men. Another librarian commented with relief that a particular library conference had avoided IT speakers.

And where are the Library IT visionaries - too often they are too busy fixing printers and cleaning up after computer viruses?

So how do we upskill ourselves, become comfortable with the technology and the jargon? My answer would be to read, read, read. Take home that copy of Computers in Libraries, print out the articles from Ariadne, D-Lib, Bibliotech Review etc. Read through the IT Weekly even if you don't understand all the buzzwords - it will slowly seep into your head through osmosis! And make time to explore that piece of software on your desktop. Pull down the file menus, open the help screens. None of us can smugly think we know enough, nor can we afford to feel "IT'd out". Library managers should regularly evaluate their staff computer skills and staff development programmes should include regular training and "top-up" sessions. They don't need to be expensive packages provided by external training agencies. If you have a library assistant who is a whizz with fixing printers ask him or her to run a session in your staff meeting.

Unless we can prove our ability to manage the changes in the information industry we are in danger of becoming marginalised and irrelevant. At the same time New Zealand librarians have a ma- 
jor opportunity to shape our country's information future. LIANZA is doing a good job lobbying the government to create a national information strategy. Our library educators are turning out committed and IT literate graduates. But we need to articulate our vision and show where we are heading as a profession. In other words walk the talk.

If you look at the increasingly public face of many libraries, our electronic front doors, you find a dog's breakfast of web sites, some with broken and out of date links, some with barely more than a list of opening hours. One library site was last updated in 1997. Few have a professional feel to them, with little thought given to design considerations, nor to marketing services to our clients. Compare our web sites to banks, real estate agents, even undertakers. Yes, we need to cater to clients with slow Internet speed and old computers, but we don't need to sacrifice all attempts at innovation. We do not exactly give the impression of leading edge, information professionals. Our web presence sometimes looks more like a cottage industry of amateur "dabblers".

True, we don't get the government grants that the Australians do, nor the research funding in Britain, but we should be doing a lot more. Here's some of my list:

- dynamic, well designed web sites that deliver up to the minute information resources

- a national digital collection along the lines of Picture Australia, where a number of libraries have digitised heritage resources and provided the metadata for a central repository managed by the National Library

- personalised information portals where clients can create their own information environments

- leadership in resource discovery on the NZ web scene (is Te Puna Web directory still being updated?)

- well managed, high profile intranets that have a vital role in organisation cultures

- regional and national digital archives for the preservation of and long term access to online publications (along the lines of NLA's Pandora)

- showcases for the use of metadata - DC , EAD, RDF etc - in information retrieval

- an ever increasing collection of quality, well organised electronic resources delivered to our clients when they want them and how they want them.

This afternoon we stopped in at the Otira Hotel, a run-down, ramshackle building with peeling purple paint and rotting weatherboards - the last survivor of a once-thriving settlement. We got talking with Bill, the taciturn publican, who bought the place (pub, railway cottages, the lot), for $\$ 63,000$ a couple of years ago! Hearing Annie mention how her grandfather had worked on the railway tunnel and her uncle had taught at the now-derelict school, he proudly brought out a photo album from behind the bar, keen to locate her family history. There was Dick Seddon in front of the hotel on his way to the West Coast, a stage coach passing through town, grainy school photos from the between-wars era...

"Did you find the photos in the pub?" I asked. "No, they're from the Turnbull Library. I got them off the Internet," he answered nonchalantly.

Brian Flaherty

Networked Information Librarian

University of Auckland Library

Ph: 373-7599 x7771 Fax: 373-7565

b.flaherty@auckland.ac.nz

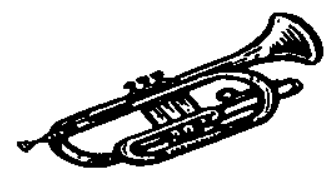

This article first appeared in Library Life May 2001 and has been reprinted with permission 